KALAM, p-ISSN: 0853-9510 e-ISSN: 2540-7759

http://ejournal.radenintan.ac.id/index.php/KALAM

Volume 10, No. 2, Desember 2016, halaman 349 - 380

\title{
Save Maryam: Islam, Toleration and Religious-Exclusivism in Social Media
}

M. Endy Saputro

Fakultas Ekonomi dan Bisnis IAIN Surakarta

m.endis@yahoo.com

Nuki Mayasari

Center for Religious and Cross-Cultural Studies, UGM nukimayasari@gmail.com

Paulus Widiyanta Jaringan Lintas Iman, Klaten

pwidiyanta@gmail.com

\begin{abstract}
Abstrak
Munginkan eksklusivisme agama bisa dihadapi di media sosial? Revolusi media yang sedemikian rupa telah membuka kemungkinan bagi lembagalembaga keagamaan untuk. menjangkau pengikutnya dalam kisaran yang lebih luas. Makalah ini akan mengamati gagasan menghadapi eksklusivisme agama ini di media sosial dengan mempertimbangkan rekonseptualisasi gagasan konvensional toleransi di era media sosial. Untuk menilai argumen ini, secara hati-hati diuji tanggapan pemuda Indonesia terbadap video bermain pendek, berjudul bintang Maryam yang dapat didownload di media sosial, seperti Facebook, YouTube, Twitter, dan blog terkait lainnya. Dengan analisis semca ini, kami berpendapat bahwa toleransi dapat didefinisikan sebagai upaya budaya untuk menghadapi eksklusivisme agama. Abstract
Can religious-exclusivism encounter be possible on social media? The
unexpected revolution of media has opened possibility for religious institutions
to reach their adherents in broader range. This paper would observe the idea
\end{abstract}


of encountering religious-exclusivism in the social media calling for an important consideration of re-conceptualizing the conventional idea of toleration in the age of social media. To assess this argument, we carefully examine young Indonesian responses toward a short video playing, entitled Save Maryam that may be downloaded at social medias, such as Facebook, YouTube, Twitter and other related blogs. Through this carefully analysis, we argue that toleration can be defined as a cultural effort to encountering religious exclusivism.

Keywords: save maryam; religious exclusivism; toleration; social media

\section{A. Introduction}

Save Maryam is a short video drawn a young Muslim girl named Maryam who faces psychological depression due to family problem, and then invited to join activities held by a Christian Church. She is being forcefully represented as an example of approximately two million Muslims in Indonesia annually leaving from Islam. This video aims to call for all Muslims in the world to pay great attention to the issue of Christianization in Indonesia. Through disseminating this video, at least, all Muslims in the world will be aware to do counter-Christianization in Indonesia.

Mercy Mission World, a world charity organization behind Save Maryam, greatly proposes to facilitate the counterChristianization in Indonesia come to exist, through planning some programs, such as building a youth Muslim TV, creating community helpline phone, and offering micro-credit for needy people. Consequently, Mercy Mission World needs approximately US\$ 2.000.000 to realize it into reality. Save Maryam is initially released on July 21, 2012 to calling donation.

Mercy Mission World itself is a charity organization grounded in the Australia, but now spreading out in UK, South Africa, India, Canada and Malaysia. The main organization vision is "to achieve a world where every Muslim can live faithfully to their belief, building exemplary Islamic communities that benefit humanity." According to Tawfique Chowdhury, a CEO of Mercy Mission World, in his release on Youtube, this charity organization eventually has not focused only on producing excellent knowledge 
institution to study Islamic Taubid, but admitting social services also. In addition, Chowdhury confidently claims to have an education institutions, named al Kautsar where Islamic Taubid weekly taught; and opening Ramadhan TV to facilitate Islamic social activism. He also definitely states that Mercy Mission World has created Zakat Foundation to empower the needy people.

Why is Maryam, why is Indonesia? Mercy Mission World stated clearly, ${ }^{1}$

To help in reviving Islam in the world's largest Muslim majority country ... . We believe that the problem of aggressive Christianization has the potential to cause serious civil unrest and social strife in the largest Muslim population in the world. As witnessed in other regions like Sudan, Nigeria and even East Timor ... Mercy Mission want to prevent Indonesian sectarian violence and wants to stop vigilantism against minorities. ... In addition to this, Mercy Mission recognizes that if we lose Indonesia to Christianity, this will send out a clear and dangerous message to all missionaries across the world: that if the world's largest Muslim country can be Christianized, then any Muslim country in the world can be taken.

Two questions should be directed to respond that statement. First, Mercy Mission World claims, "Christianization has the potential to cause serious civil unrest and social strife." This argument does not have any empirical evidences in Indonesia. Mostly, conflicts suspected as religious conflict is primarily triggered by political economic factors, rather than pure religious issue; taking for an example the conflict of Moluccas. ${ }^{2}$ Second, the statement that "Mercy Mission want to prevent Indonesian sectarian violence and wants to stop vigilantism against minorities" is being so utopian idea raising a main question who is considered

1 Quoted from Frequently Ask Questions, which is published on savemaryam.com, accessed March 11, 2013.

2 See for a further example Gerry van Klinken, "What Caused the Ambon Violence?" Inside Indonesia, no. 60 (Oct-Dec 1999); retrieved on March $12,2013$. 
as minority here? Presumably, Mercy Mission does not realize that Christian people in Indonesia has been considered as one of minorities in Indonesia.

Interestingly, the practice of Mercy Mission World massively disseminates a short movie implies the use of social media in the sake of religious issue. Why does religion need media, including social media, to deliver its idea of dakwah? In the following section, we will brief frame the issue of religion and social media, including its possibility to cover the matter of interreligious dialogue. We argue that interreligious dialogue is possible conducted in social media because its interactive factor.

\section{B. Religion in Social Media}

The coming of television has frequently considered as the end of religious institutions. In Indonesian context, for an example, Kuntowijoyo, a Muslim prominent figure, argues that we are entering the era of "muslim tanpa masjid" (muslim without mosque). The main character of this era is that television plays important roles for mainly Muslim middle class in spreading out the teaching of Islam that before is greatly managed by certain religious institutions, such as pesantren. Consequently, changing religious authorities take place, namely from kiai to television. In bahasa this condition called tontonan jadi tuntunan, meaning TV program is better to guide people who watch it. ${ }^{3}$

TV stations then take this opportunity to display varieties of religious programs. Popular preachers then emerge along with their unique characteristics. In addition, for some 'religious' organization, television providers become a property to deliver religious teachings, for an example of ADi TV from Muhammadiyah that offers programs related to Islamic teaching in whole days. As results, this condition may lead two critical notes.

${ }^{3}$ Kuntowijoyo, Muslim Tanpa Masjid: Esai-esai Agama, Budaya dan Politik dalam Bingkai Strukturalisme Transendental, (Bandung: Mizan, 2001); Bryan S. Turner, "Religious Authority and the New Media," Theory, Culture and Society Vol. 24 (2), 2007, pp. 117-134; Peter Mandaville, "Globalization and the Politics of Religious Knowledge: Pluralizing Authority in the Muslim World," Theory, Culture and Society Vol. 24 (2), 2004, pp. 101-115. 
First, the TV programs may concern on majority's interest, in doing so it may marginalize minority and not possible raising intention for the minority to establish his TV station. Second, this condition provokes the exclusivism paradigm toward the other religions. The reason is that TV station now become a meaning that express certain religious identity. ${ }^{4}$

Television is being categorized as old media differentiated from new media. On one hand, the old media is passive, meaning that the audiences just watch on the screen display. On the other hand, the new media provide a space for being interactivity. ${ }^{5}$ In addition, the new media open possibilities for users to express their identities, narrations and emotions. ${ }^{6}$ This considerations open possibility for the new media to be a space of testing toleration.

According to the Doyle Building Tolerance Initiative, apart from its effectiveness, social media, such as Facebook, provides "safe place" for conducting dialogue, as a means of toleration, on some religious issues. Some groups, for examples are Faithbook, Beliefnet, and Peace.Facebook, shows how people across the world share their experience doing the cultures of tolerance on certain issues. However, in our view, this organization surprisingly offers a definition of dialogue that difficult to cover the dynamic of dialogue in the social media. They states, "Dialogue is an open conversation on a shared subject between two people or groups of people, with a goal that participants learn from the other so that they may change, grow and come to better understand their own beliefs in a greater context." Furthermore, this organization emphasizes that a key word of dialogue is that of "respect, trust and openness." In the Doyle's view, seemingly, dialogue in the

4 See the changing pattern of television from medium to meaning in Stewart M. Hoover, Religion in the Media Age (London and New York: Routledge, 2006), chapter two, respectively.

5 See further Andrew Dewdney and Peter Ride, the New Media Handbook, (London and New York: Routledge, 2006).

6 Jose van Dijck, "You Have One Identity: Performing the Self on Facebook and Linkedln," Media, Culture and Society 35 (2), 2013, pp. 199 - 215.

7 The Doyle Building Tolerance Initiative, Bridging Babel, pp. 3 - 5. 
social media is situated similar to the dialogue in reality. It seems that the Doyle's dialogue is pinpointed in the theological level. ${ }^{8}$

In the following section, we challenge the Doyle's view on dialogue by arguing that in the social media the act of religiousexclusivism encounter is conducted for the sake of showing arguments apart from "respect and trust" and understanding. At the same time, their arguments show directly their religious identities. For us, this definition of dialogue brings the condition of real dialogue come to exist, imagining that there is exclusive, inclusive or pluralist people come together conducting dialogue. ${ }^{9}$ This dialogue, put it more aptly, we post in the culture of toleration.

\section{Varieties of Save Maryam Responses}

This section analytically analyses the responses toward Save Maryam. To see the characters of the responses, we divide the explanation based on three different social media, namely; Facebook, Twitter and YouTube and other related websites. We show how the response represents the user's identity. Generally speaking, there are two main response, which are pro and contra toward Save Maryam.

\section{Facebook}

As aforementioned, Save Maryam was initially launched on July 21, 2012. When we accessed it on early March 2013, 90.276.400 people liked this video. Mostly three responses provided in this initial launching are first, praising the launching of this video; second, recommending to not support this video; and third, asking the validity of the number 2 million people annually converted from Islam.

Studies, 2003.

8 Leonard Swidler,"The Dialogue Decalogue," Journal of Ecumenical

${ }^{9}$ For the definition of three categories, see Diana L. Eck. "Is Our God Listening? Exclusivism, Inclusivism and Pluralism," in Roger Boase (ed)., Islam and Global Dialogue: Religious Pluralism and the Pursuit of Peace, (Burlington: Ashgate, 2005), pp. 21 - 49; Fatimah Husein, Muslim-Christian Relations in the New Order Indonesia: the Exclusivist and Inclusivist Muslims' Perspectives, (Bandung: Mizan, 2005), pp. 27 - 31. 
Muhammad Rafiq Christian missionary groups get so much funding. Now that Muslims are trying to do something, people are not supporting.

Rejstar Reji This a project iv put my whole heart and soul into, it is about 'Islam' and how the world is today.

Syafa Syafirah Indonesia is really a troubled country. they have problem attitude, high poverty rate, and they are confused about their self. yet, they still argue with their brother, Malaysia. I am also a Malaysian, and I will help to share this mission. semoga allah melembutkan hati org2 smuslim, khususnya Indonesia supaya kembali ke pangkal jalan. dan berdamai sesama negara2 ISLAM

Madina Rustaqi 2 Million leave Islam EVERY year? That is 7600 Converts EVERY SINGLE DAY?! ... umm hello? I haven't found any source about this online. Nothing official...

Abednego Tanuwidjaja why cant we just live in peace, for some people this video is all it takes to create sorts of problem in Indonesia

Amirul Amin It is sad to see when people trying to do something to save the deen of Muslim, there are those who call them self as Muslim but did not support it and actually give negative comments and even make fitna about this effort when people who are making this efforts are ulama.

How can you believe $\mathrm{Mr}$ Google more than the scholars of Islam and actually making fitna on them? How can you say we should just close our eyes on this problem and live "peacefully"? Should I remember to you about what happened to Ambon? Do you think they will live us in peace? Where is your love for your brothers and sisters in Islam? Where is your Iman???

My question is, what have you done to help? Everyone need to ask that question to our self. Everyone can be a critics or a beroes in the internet but when it comes to the real world how many actually do something about it?

On the day after, Save Maryam posted the video. Interestingly, there was a response that said, "Why the people in 
Save Maryam Mercy Mission World Action Plan not included people from Indonesia? its very strange to me." Tawfique Chowdhury, the leader of Mercy Mission World answered, "We do have a lot of team members in Indonesia and we work with Muhammadiyyah. So says who we havn't included Indonesians?" This dialogue continued on September 28, 2012. Save Maryam team posted the status that their team had visited Darut Tauhid, Bandung to make cooperation with this organization, but it was rejected.

Tomy Satyagraha DT doesn't join collaboration with savemaryam project not because DT supports christinization or againts dakwah, in fact DT is one of many organization in Indonesia who help muallafs. Almost every week there's always new muallafs give syahadah in front of jamaah after sermon and DT also provide shelter for unfortune muallafs. DT make a decision not to join collaboration with savemaryam because it is started with manipulative actions which have been revealed. The campaign itself just making indonesian dakwah a bad name in front of international communities

Light upon Light Yusoff I don't think think anyone wants to undermine any effort made by DT in Indonesia or implying they are against the campaign. Decision made are respected insya Allah. The research and suggestion to visit DT was made by the students of DT. May Allah reward DT jemaah specially the Daie's for all the effort in spreading dakwah

Bintang Winata Yusoff you said "I don't think think anyone wants to undermine any effort made by DT in Indonesia or implying they are against the campaign." That's what I exactly felt when SM wrote the first paragraph about their visiting then followed by the next paragraph. Why should SM's update about the meeting followed by this words "In doing da'wah, it is Sunnabtullah that there will be people who support it and there will be people who are against it." what's SM motivation and goal? You post/share the same thing in another post, but SM doesn't consider it as a spam, while others do the same thing with the different content which questioning SM but SM consider it as spam. What is it? 
LightuponLight Yusoff I like to have husnu ron. That's all. Assume the good always. You are entitle to your feeling, I choose to have positive feeling. Just thought I should share this, Rasulullah s.a.w teach us to have at least have 70 excuses if we feel our brothers or sisters made a mistakes. I would like people to do the same for me. May you have a blessed day Akhi. Ameen

Bintang Winata Thanks Yusoff for your explanation about khusnudzon. Now, would you belp me please to make me kbusnudzon by answering my question, why should SM need to wrote those paragrapsh after reporting the meeting with DT? You work for MM, dont you? FYI I'm female.

LightuponLight Yusoff I have sent a message to answer your question your fb page yesterday ukhti. Brother dzul qarnain please be patient and mind our Adab in our communication.

Bintang Winata I didn't find any message from you, Akbi Yusoff. Well, since the post is published here, I hope you or admin answer me here as well. Mind it?

Zulkifli Hidayat I think I can see to whom the paragraph is directed to, I am sure it is not DT

LightuponLight Yusoff I truly believe that it's best to stay away from assumption in any case. Too many assumption on SM has been going on and I'm not sure it's good to do that and the latest on the photos of SM and IC. Assumption again kang tommy. Opinion is one thing, assumption is another and it can leads to Allah bu alim, bad thoughts. To present a figure as a data from a research will always has its strength and "problem" as any research students would agree. At the end of the day how do we use that data to prove our hypothesis. Hjh Irena said something very profound on this data issue that on the ground level how the missionaries able to manipulate it to convince the authority that the amount of converts that they claimed has happened. Again, truth be told, the problem of conversion exist. We can argue to the end of time about numbers and anyone pursuing their masters or phd will go through this process and understand if they are doing quantitative research but how do you conclude that they is issue or problem in the society that you as a weak human being try to contribute to belp 
solved the matter. This is my personal opinion and as all our Ulama' and Imams would always say and I hope I can follow their footsteps by the will of Allah" my opinion can be right, and it can be wrong". One thing for sure Allah is never wrong and everything from Him is always GOOD! Allah knows best.

Generally, those who supported Save Maryam were provoked by the issue of Christianization. The responses that agree with Save Maryam questioned those who disagreed. They questioned what have be done for those who not supported Save Maryam to prevent Christianization in Indonesia.

Muhamad El-faris Shyne-moros saya kira dengan adanya page ini menerangkan bahwa ternyata kristenisasi itu ada Indonesia dan sebagian kita tak sadar dan itulab sebabnya diinfokan oleh saudara kita sesama Muslim di beberapa negara yg pribatin dengan keadaan bahwa Indonesia negara Muslim terbesar di dunia mengalami degradasi jumlah muslimnya per-tahun berbanding terbalik dengan negara di eropa dan Amerika yang mengalami peningkatan (mungkin statistik berbanding terbalik ini yg membuat beberapa orang cenderung Skeptis dengan info dari page ini ditambah yg mengalami penurunan adalah negara yang menjadi mayoritas penduduknya adlah muslim). Terlepas benar atau tidaknya statistik babwa setahun lebih dari 2 juta orang muslim (saudara kita yang muslim tersebut lebib banyak yg berada dalam di dalam garis kemiskinan yg memang rentan akan bahaya kritenisasi) seharusnya kita menjadi lebih aware (waspada) karena bisa kita bayangkan kita gk langsung sadar dengan keadaan tersebut dalam beberapa tahun.... wallabuallam

Husam Baradja Bikin TV pasti saya dukung.. Buat orang indonesia, kalo kalian bisa coba bikin to dong bukian banyolan aja apalagi yang kerjaannya "memonitor save maryam" day and night, sudah bikin apa kalian buat islam ?? kenyataannya kristenisasi lagi gencar2nya sekarang ini.. yang dipermasalabin 2 juta terus ya.. basi, 2 jutanya sudah diganti tub lo diposternya. gereja2 di Solo sudah pada dibangun tuh. yang tadinya gentengnya bisa disentuh sekarang udah tingkat 5 ato brapa.. kristenisasi babkean budhanisasi digunung kidul dan ditempat-tempat lain.. allabul musta'an 
Hawa Khoirunnisa beberapa hari yang lalu sy dengar ceramah salah 1 radio swata di bandung. ustadnya menceritakan bhwa awal agustus akan diturunkan ke salah 1 wilayah di jawa barat karena disana sdg ada kritenisasi. beliau memohon doa dan support bantuan dana utk mengumpulkan alquran utk dibagikan di sana... kl tdk percaya cb dengar ceramah islam radio Sonata 88.1 MHz tiap hari jam 6-7 pagi (itu jdwl sebelum Ramdhan)... kira2 stgh thn yg lalu misionaris domplengi program Mobil Pintar untuk. menyusupkan misi kristenisasi di beberapa SD Negeri dan SD Islam Bekasi berita pernah dimuat bbrp media elektronik.. ayolab BUKA Mata dan Telinga.. malu sama org luar negri yang justru pribatin dg keadaan kita $T_{-} T$ berita itu slh 1 nya dimuat di bttp:/ / wmw.voa-

islam.com/news/indonesiana/2011/10/18/164 28/baptismassal-sd-bekasi-misionaris-mobil-pintar-nodai-duniapendidikan/

However, for those who does not support this campaign, questioning the validity of data displayed on the video. Other responses try to remind the spirit of peaceful solidarity in Indonesian context. The Christianization may be real, however, the response says that it should be solved properly, not display the wrong data in provocative ways.

Save Maryam We posted a couple of days ago a question, if we were to remove the 2 million report of people leaving Islam, would all those people against the campaign then be interested in supporting it? Interestingly non of the people who had an issue with the 2 million reported. Could it be all those resisting the 2 million are actually people who do not mind people leaving Islam and are actually trying to distract Muslims from uniting to strengthen the call to tawheed?

Satrio Wicaksono The fact that you consider these views are minority is another proof that you have no idea what you are dealing with at the grassroot in Indonesia. Most of the posts that raises a valid logical question here was met with words like "fasiq, munafiq, and bypocrite", which is a shame. And thank you for posting that 2-million-explained. Firstly, there is no source or reference to address the origin of such numbers except subjective 
words like "I have been to Indonesia", "Many" etc. Secondly, suppose that 2 million number is true, your best solution is to bave a TV station?...W Wow, you are really out of touch with the grassroots. If this turn out to be a legit fundraising, I wish you good luck, you really gonna need it.

Hadiyan Faris Azhar i'm indonesian,, this is real brother and sister, my family have madrasah in the middle of central java, that struggle to protect muslim being murtad... this is happened cuz of proverty... the missionary provide assistance to the poor people, to belp them get out from the proverty, with condition they must be murtad from Islam and convert to cristian...i see this with my own eye... here's the valid data in 1990 indonesia have 179.378 .946 people, and 97,5\% of them are Muslim, so the Muslim is ... and now Indonesia have 244.775.796 People, and Muslim just 83\%.... Indonesia Muslim are Increase, but non Muslim more Increse than Indonesia Muslim... this is because "pemurtadan" Activity by the Missionary... this is real... and its happened in Indonesia... because of that very large number and very large area.. many muslim people of Indonesia not awware with this condition...

Adrian Janitra Putra Dear Mr. Dzul Qarnain, actually the "west" has started to talk GOOD about muslims, especially the more civilized, tolerant and educated ones. This campaign is only going to DESTROY this reputation by using LIES, MANIPULATONS and AGITATIONS.

Sari Rahmayati First, thank you for you and your team because you have concerned about us (your sister and brother moslem in Indonesia) That's keep our brotherhood in Islam that our prophet want it. Second, I do not want to bide the fact about christian missionaries in Indonesia. Like near my home there are people who are converted their religion from Islam to christian. But do you know that Indonesia is a big country with many ethnics, culture, and religion? you have to know that in Indonesia our Government admit 6 religion; Islam (Majority religion), Christian protestant and Catolic, Hindu, Buddhism, and Konghucu. The citizen of Indonesia is free to take one religion.. Based on the diversity, we always tolerate each other. That is our holy Quran nur kareem teach us to tolerate, right? like in Surah Al-kafirun. you are for 
your religion and I for my religion. and we can not to bide the fact there are many people in Indonesia who converted from other religion such as Christian, bindu, and buddhism to Islam too. If you want to belp us you have to know us well. You have to learn our history. How Islam come to Indonesia and spread widely and now become the majority religion in Indonesia. How Islam can touch people in Indonesia. And you should know that Indonesia has many islands. Eventhough Islam is the majority religion in Indonesia but in every Island has different majority religion.

\section{Youtube and Twitter}

Youtube is one of the important sources for publishing Save Maryam content. However, there are just a few comments of internet users' in Youtube. Two comments are notably written below the video of Save Udin and no comment is written below the video of Save Maryam. The first comment in Save Udin video in youtube came from Abdullah Mujaddidi on August 2012, which is "LOL" or simply means "Laugh Out Loud". The second comment on Save Udin videos came from an internet used named fadhlanPKZ on August 2012, which was actually a citation of An Nahl, one of the Qur'an verses, implying to nicely warn people to be engaged in the God's way and a further comment in Arabic.

Serulah (manusia) kepada jalan Tuban-mu dengan hikemah dan pelajaran yang baik dan bantablah mereka dengan cara yang baik.

Sesunggubnya Tuhanmu Dialah yang lebih mengetahui tentang siapa yang tersesat dari jalan-Nya dan Dialah yang lebih mengetahui orang-orang yang mendapat petunjuk (An Nabl: 125). Laa tahzan innallaha ma'anaa! Ma'an najab! :) (Save Udin, August 2012)

The comment above is mainly implying on the urgency of promoting people to keep staying in the right track. Moreover, the comment also implies that only God who knows that people are taking a right path or a wrong one. Unfortunately, there are just a few comments in Youtube. More comments about these two videos can also be seen in twitter.

Comments about these two videos were massively delivered via twitter account by using which can be seen by the using of 
hashtag along with mentioning the twitter account of Save Maryam and Save Udin videos. Moreover, comments about the videos in twitter are apparently related to international twitter user. Various hashtags ${ }^{10}$ were found in the comments of Save Maryam video, which are: \#SaveMaryam, \#MaryamMenggugat, \#SaveUdin, \#Indonesia, and \#MercyMission. Comments about Save Maryam can be grouped into three main categories, which are: contra and pro, which will be discussed in the further sections.

\section{Contra Comments}

Responding Save Maryam, myriads of twitter users are notably taking a contra position on the content of the video. Being variously influenced by some reasons, the contra reaction against the videos in twitter can be seen through the following comments. Started with a light contra comment by a twitter account named @_maryambee on 12 February 2013, that saying "I didn't even know about this girl's existence until today lol. \#SaveMaryam", implies that the reliability of Save Maryam video is questioned. Other comments seem to be stricter questioning the validity of Save Maryam, which can be seen through these following comments:

"...mungkin bisa baca bukunya: "\#MaryamMenggugat:

Menguak Propaganda \#SaveMaryam": http://youtu.be/ EjFs UuP21U“"(MaulanaSyuhada, 8 February 2013).

"For all the Moslems wherever you R, pls watch $\mathrm{N}$ share this video, a video bout \#SaveMaryam lies. https:/ / www. youtube.com/watch?feature=player_embedded \&v $=$ pOs GG_Znfy0...”. (@santosa_dbayu, 27 December 2013).

The two comments above are mainly implying about the invalid content of Save Maryam by also denoting that the video is propaganda. The first comment promotes the people to read a countering source, a book entitled Maryam Menggugat. The second

10 Hashtag (noun) is a: (on social-networking Web sites) a word or phrase preceded by a hash mark (\#), used within a message to identify a keyword or topic of interest and facilitate a search for it (http://m.dictionary.com/d/?q=hashtag) 
comment is mainly courage people to watch and share the countering videos about Save Maryam, by also implementing that the content of Save Maryam is invalid.

Another disagreement about Save Maryam content can also be seen through the publishing of opinions that Save Maryam is invalid by making relation to scam and publishing the invalidity through an article. The comments related to the topic can be seen as followings:

"In case you are wondering. \#SaveMaryam is a scam like KONY - watch this video - http://bit.ly/ZZlB8U" (@1Obefiend, 17 January 2013)

"My latest article about \#SaveMaryam : Know Maryam Before Saving Her http://www.onislam.net/english/ culture -and-entertainment/media/459546-knowmaryam-before-saving-her.html\#SaveUdin \#Indonesia\# MercyMission”(@yelsaeed,17 October 2012).

The two comments above imply on the invalidity of Save Maryam's content by also using concept of scam and making a counter article. The first comment employs an idea that Save Maryam is a scam, similar to Kony case. The second is mainly implying on the similar idea about the unreliability of Save Maryam by also stating a link of a countering writing for the video, which made by a twitter account named@yelsaeed.

Along with the comments against the content promoted by Save Maryam video, a discourse about Save Udin, which is considered as a countering video, is promoted. Promoting the content of Save Udin, which content is considered as promoting the concept of toleration, some comments related to the emergence of Save Udin as a countering video can be seen as following:

"RT@MaulanaSyuhada:untuk counter \#savemaryam saya dan teman2 membentuk \#saveudin.cek webnya di http://saveudin.org@bentangpustaka”.(@salmanfaridi, 8 January 2013)

“@alyahzie atau gabung di \#SaveUdin, FB-nya http://www.facebook.com/MyNameIsUdin, Save Udin 
itu gerakan yang mengcounter kampanye \#SaveMaryam" (@MaulanaSyuhada, 28 December 2012).

The two comments above are mainly denoting on the invalidity of Save Maryam and employing the people to watch Save Udin as a countering source. Moreover, the two comments are written by twitter account named @MaulanaSyuhada, the author of Save Udin video. The first comment is promoting Save Udin as a countering video for Save Maryam, by also attaching the link of Save Udin, which more or less means that "for countering Save Maryam, me and some friends are forming Save Udin". The second comment is mainly encouraging people to watch Save Udin video and join the countering campaign for Save Maryam discourse in Facebook, which was intended for a twitter account named (a)alyahzie, by also stating the link of Save Udin campaign in Facebook.

Responding the emergence of Save Udin, some twitter users are also commenting on twitter in order to promote Save Udin. Some comments related on how people perceive Save Udin, in contrast to Save Maryam, and promoting the video at the same time, can be seen as followings:

"Religion teaches us LOVE, NOT HATRED! \#SaveUdin rejects \#SaveMaryam's propaganda and lies (abentangpustaka pic.twitter.com/vtDuq6Cko9" (aSaveUdin, 3 April 2013).

"\#SaveUdin- a great campaign set up by Indonesian Muslims encouraging religious tolerance in response to \#SaveMaryam. http://www.saveudin.org/saveudin/" (@rima246,26 August 2012).

"(Indonesia) Kompasiana: \#SaveUdin dan Tampilnya Gelombang Muslim Muda Moderat Indonesia http://www.saveudin.org/indonesia-kompasianasaveudin-dan-tampilnya-gelombang-muslim-mudamoderat-indonesia /...”(@ypantou, 27 August 2012).

The three comments above are mainly employing on the content of Save Udin as a toleration promoter, by also making 
relation to the notion of what religion shall teach. Moreover the comments are also implying on the invalidity of Save Maryam; so that, people shall watch Save Udin as a countering source. The first comment employs on the notion of religion, which actually promotes love, in contrast with the content of Save Maryam campaign. The comment is also emphasizing on the position of Save Udin as a counter campaign for Save Maryam, by also implying that Save Maryam campaign is invalid. The second comment presumes that Save Udin is a toleration movement which done by Indonesian Muslim as a response for Save Maryam.

Conversely, in this extent, Save Maryam is apparently considered as a segregating promoter video. In addition, the third comment denotes Save Udin as a countering movement from the Moderate Indonesian Muslim who promote religious tolerance. Moreover, the emergence of Save Udin is also followed up by a Public Letters of Indonesian Citizen for Indonesian Embassy in London, which can be seen in a following comment:

"Join The Force! \#SaveUdin (Indonesia) Surat Bersama Warga Indonesia kepada Duta Besar RI di London http:/ /www.saveudin.org/indonesia-surat-bersamawarga-indonesia-kepada-duta-besar-ri-di-london/..." (@FadhLan_GazettE, 26 August 2012).

The comment above, which more or less means to encourage people to join the movement by also participating on the Public Letters addressing Save Udin as an Indonesian movements for promoting religious tolerance, in order to countering the content of Save Maryam video.

Completing comments against Save Maryam campaign, the author of Save Udin, Maulana M. Syuhada, presents the current condition of Save Maryam's tools of campaign. The accounts for campaigning Save Maryam is, according to Syuhada, unwell maintained, which can be seen in the following twitter comment:

"\#SaveMaryam FB and website have been abandoned.
Their FB is now full of spams. Check:
http://www.facebook. com/whoismaryam"
(@MaulanaSyuhada, 8 April 2013)


In the comment above, Syuhada who have a twitter account named@MaulanaSyuhada, implies that the Facebook account and Website of Save Maryam is currently unwell maintained. Moreover, the Facebook account is currently full of spam. This comment presumes that the Save Maryam campaign is no longer insisted on the two media or can also be predicted that the campaign may temporarily be stopped.

The emergence of Save Maryam video is unwell responded by the twitter users. The comments written in this section is just a part of contra opinion of Save Maryam. The main idea of countering Save Maryam is mainly by looking at the content validity of the video. In addition, people who are disagreeing with the content of Save Maryam are finally forming a countering movement named Save Udin. In this extent, Save Udin tends to be related as a movement of Indonesian who are actually promoting religious tolerance. This promotion is definitely contrast with the content of Save Maryam which promoting the potential extinction of Muslim in Indonesia due to Christianization, which can also be seen as promoting religious segregation. In other words, the Christianization content of Save Maryam is also responded as a segregation promoter which not originally rooted on Indonesian culture; so that, the formation of Save Udin is mainly bringing the opposite content, which is the concept of religious tolerance as the real Indonesian culture.

\section{Pro Comments}

The content of Save Maryam is diversely responded by the twitter users. Being partly disagree with the campaign promoted by Save Maryam, some twitter users are notably agreeing the content of Save Maryam. The urgency of saving Muslim from extinction due to Christianization is an important point of promoting Save Maryam. In addition, the risk of losing Indonesian identity as the biggest Muslim country due to the annual declining of Muslim population is also implied here. The variation of people promoting Save Maryam through comments in twitter can be seen in this section.

Responding Save Maryam, some people are notably supporting the content of the video, by mainly making a relation to 
Islam preservation and the urgency of protecting Indonesian, which are dominantly Muslim, from Christianization. Related to the concept of saving Indonesian from Christianization by promoting Islam preservation can be seen in the following comments:

"Buka deh: http:/ / savemaryam.com keren loh, isinya tentang proyek menyelamatkan Islam Indonesia \#Save Maryam”(@SangAmin, 11 May 2013)

"This is why we must preserve the name Allah \#savemaryam Save Maryam http://flip.it/4a3H8" (@)shukeran, 14 January 2013).

The two comments above are mainly implying on the importance of saving the population of Muslim in Indonesia in order to preserve the name of Allah. The first comment is encouraging people to open the Save Maryam website and mention it as a project to save Islam in Indonesia. In addition, the second comment implies that Save Maryam movement is equal to protecting the holiness of Allah.

Promoting the content of Save Maryam, some twitter users are notably posting tweets only for promoting the video without really commenting about the video content. The promotion of Save Maryam, without implying the content of the video, can be seen in the following comments:

"Watch the video, dont just scroll it. Save Maryam spread the word: http://youtu.be/S6oDKyPmDgk via @youtube \#SaveMaryam \#SaveIslam"(@ezzumi, 25 April 2013)

"Watch this video and Share it http://bb1.co/-BB288550C0-MPs ... \#savemaryam $<3$, this case should have your attention" (@zinabsaad,6 September 2012).

The two comments above are mainly implying on the promotion of Save Maryam, without really stating perceptions about the video content. The first comment promotes people to watch Save Maryam video, by also putting a hashtag of Save Islam. This means that Save Maryam campaign is still related on the 
concept of Saving Islam, through the using of hashtag. In another hand, the second comment is implying on people to watch and republish the video by sharing it in their accounts. In addition, this comment is also stating that the Save Maryam case shall get people attention, without using any other hashtag but Save Maryam.

Agreeing the content of Save Maryam, some twitter user also making relation between the Save Maryam video with the statement of KIBAR (Indonesian Islamic Society of Great Britain). The relation between the two things can be seen in the following twitter comments:

"Kibar: Kampanye \#SaveMaryam Tak Dimaksudkan Merusak Kerukunan Umat Beragama di Indonesia http://hidayatullah.com/read/24515/30/08/2012/kibar: -kampanye-\#savemaryam-tak-dimaksudkan-merusakkeru kunan-umat-beragama-di-indonesia.html...Cc\#save UDIN\# bedaISME \#kode”, (@huda183,2 September 2012).

"Jadi kita dukung penuh \#savemaryam ya? :) RT @ malakmalakmal: Pernyataan dari KIBAR mengenai \#SaveMaryam http://bit.ly/NDnDpp”. (@hafidz_ary, 31 August 2012)

The two comments above are mainly implying on the statement of KIBAR which tend to support the Save Maryam campaign. The first comment states that in accordance to KIBAR, the content of Save Maryam campaign is not intended to promote religious intolerance in Indonesia, by also stating the link of an Islamic online magazine named Hidayatullah. Furthermore, the second comment encourages people to fully support the Save Maryam campaign by also stating the link of KIBAR's statement about the video.

The following supporting comments on Save Maryam campaign is related on the content of Christianization promoted on the video. Being emphasized on the video, the potential extinction of Muslim population in Indonesia due to Christianization is stated by some twitter users, as seen in the following comments: 
"many muslims are leaving islam every day.. \#savemaryam

http:/ /www.youtube.com/watch?v=q3kTXk2nV7g\&sns =tw...via@youtube", (@AmiraReda_xoxo, 21 August 2012).

"\#SaveMaryam, save pemuda-pemudi Indonesia dari pemurtadan? $\quad \underline{\mathrm{htp}}$ ://fb.me/23Klg2QgT", (@GhurabaaNews, 7 August 2012).

In accordance to@AmiraReda and@GhurabaaNews, the two twitter users writing comments above, the urgency of saving Muslim population in Indonesia shall be immediately done. This opinion is definitely aligned with the content of Save Maryam campaign. The fist comment implies on the urgency having awareness that myriads of Muslim are leaving Islam every year in Indonesia. The second comment employs on the importance of protecting Indonesian youth from apostasy. The two comments are actually aligned with the main content of Save Maryam campaign.

Responding the Save Maryam video, numbers of twitter users are notably supporting the content of Save Maryam campaign. Started with encouraging people to watch and share the video, some twitter users are also promoting the urgency of understanding the content of Save Maryam. Maintaining the number of Muslim population in Indonesia by keeping them from Christianization is an important content that is implied by some twitter users. In addition, the urgency of saving Indonesian youth from Christianization is also implied in the further comments. In this extent, Christianization tends to be considered as equal to apostasy. Another comment related to Save Maryam campaign is by also relating the video to the statement of KIBAR, which countering the opinion that Save Maryam renders religious intolerance. In another words, Save Maryam is also perceived as an important source for promoting people awareness in the term of Christianization. However the video is also perceived as not promoting religious intolerance. 


\section{Blog and Other Sites}

Many people who consider the movement awkward because there's so much data that they appear in the video campaign questionable. There are loudly saying that Save Maryam is a scam, deception, there are also those who say that they are right because the name Tawfique Chowdhury who is behind the scenes of this movement is one preacher who has a name, also about organization Mercy Mission World that have enough name in several countries, including the dai-dai who also took part in the Mercy Mission World. There who prefer to wait for further information about this because he believed that the Save Maryam is a movement that aims to build awareness coupled with the names behind the project, however, assume that the methods used are still not quite right.

There is a journal written by a blogger in Multiply named Iwan Yuliyanto. He wrote that there are some irregularities in the campaign Save Maryam, also expressed disappointment with the parties that took part in spreading the campaign which he said is less responsible, both the data and the transparency of the funds managed by the creator of the campaign.

Within a week was watched by approximately 80 million people from around the world, making this the fastest-growing viral video of all time. In his narrative, Jason Russell (filmmaker) said that his campaign has purpose to pressure international governments to arrest Joseph Kony who forcibly recruit child soldiers in Uganda into supporting the so-called Lord's Resistance Army.

This video is so spread quickly, as it contains an emotional story, easily understood message, at the end of the video there is a step-by-step is so simple as to what viewers can do to start acting now. It also involves taste makersseperti musicians, artist, television host, businesswoman, officials who have a "strong voice" in making state policy. With big names behind this movement, certainly not difficult to make a viral at the time. Support donasipun flowing with swift.

Invisible Children makes the whole movement is focused to produce a major impact. They also invite all supporters of Kony 2012 to shut down the streets with posters, banners, or whatever 
they could to show support. At first it all seemed so convincing. Until one day, the lie is wafted movement. Mashable is one of the first to question the media's movement. Through his article "Kony 2012: Is the Viral Campaign A Scam?", They discussed the idea came from a blog: Visible Children. This blog is dedicated to discussing the strange findings about Kony 2012 and the Invisible Children organization. Media pleased with controversy, so the news is controversy surrounding the enlarged and into the mainstream media. That in the end the mission lies terkuaklah this movement. The video makers were later caught. He proved to have misused donations collected from all over the world.

Some responses are counter to Save Maryam is considered that this campaign is dishonest, deceitful, not "ahsan" and unscientific. From their signs, the idioms used, bombastic numbers, and sensational video; many are actually suspicious that Save Maryam is not anti-apostasy, but instead, fundraising for missions. They deplore the persistence of some Muslims who continue support the Save Maryam's campaign in the pretext to fight the Christianization. They agree that Christianization might exist, but they are invited to respond to this campaign with a more objective, using the compass of religion and science reasoning. They hope, do not let this campaign sparkling luster blind faith and mind. Also, there are reacted angrily to Mercy Mission World because the facts are displayed full dramatize unreal. In addition to anger, embarrassment to their Christian friends and other religions also appear: "How could a peace-loving religion that he uses vulgar and provocative in the way of his mission," they told. Moreover, their fear; the video could potentially trigger for inter-religious conflict and radicalization in Indonesia.

This campaign is dishonest, deceitful, not "ahsan" and unscientific; from their signs, the idioms used, bombastic numbers and sensational video. Also, there are reacted angrily to Mercy Mission World because the facts are displayed full dramatize unreal indicated are actually suspicious that Save Maryam is not antiapostasy, but instead, fundraising for missions. They use economic "episteme" (framework or paradigm) analysis background, that the campaign is aimed to collect money. 
Allegedly, the Save Maryam's video begin circulating in the Pakistani community was assessed for those who are contra as one example of the cultural clash between Pakistan and Indonesia. Deployment video Save Maryam are vulgar and provocative is a proof that Mercy Mission World does not know the culture and conditions of Indonesia. The contras found that the name "Maryam" is not a popular name for Muslim women in Indonesia. Called also that the use of English and Arabic in the video and not using the Indonesian language, is also a proof of ignorance Indonesianity context. Further: "How they will be successful preaching, if they do not understand their local culture and impose implemented in Indonesia, it will only create a new conflict?" So they asked. They then compared to what is done by the Wali Songo considered quite successfully Islamized Javanese preach contextual; according to the culture of the population in Java, such as entering through the doors of agriculture, commerce, politics, art and so forth.

The Save Maryam's video begin circulating in the Pakistani community was assessed for those who are contra as one example of the cultural clash between Pakistan and Indonesia. It is more theological-ideology forging Indonesian Muslim to embrace taubid and Islamic knowledge which is considered as a main problem of Indonesian Muslims leaving Islam. In fact, the main problem of Indonesian Muslim may be located in the social level: hungry and prosperity. Save Maryam does not address the real problem in Indonesia. They intend to counter-Christianization with Islamization.

The "Save Maryam" campaign, which holds an uncanny resemblance to Kony 2012, is the other side of a double-edged sword. The aim of the campaign is to raise $f^{2} \mathrm{~m}$ to bring Islam back into the lives of Indonesian Muslims who are converting to Christianity. Although the intentions may be positive, the campaign's video may mislead viewers and potentially be interpreted to demonize Christianity. The video also risks insulting the millions of practicing Indonesian Muslims as they are depicted as weak and without the knowledge of Islam.

Contextual codes are embedded to send out the message that Christianity is stealing people from Islam. When referring to Christianity the word "them" is emphasized, suggesting "they" are 
an opponent and detached from the audience. This allows the narrator to be on the audience's side offering the solution to the dilemma, playing in-tune to a good versus evil dichotomy.

Depicted as lost and vulnerable, 14 year old Maryam is passive to propaganda delivered to her via TV channels and helplines provided by Christian missionaries. Christians help "shut away her problems and give her a sense of peace" implying her problems have not actually been resolved and the peace she has is false. According to the campaign, Islam must set up TV networks and phone lines to propagate their ideologies. The video calls the situation an "alarming" and a proclaims a questionnable figure that 2 million Muslims are converting to Christianity each year. The campaign manifests on the inner-most fears of Muslims by threatening to take away what is most important to them; Islam.

As well as suggesting those practicing other religions are doing so because they are being manipulated, "Save Maryam" irresponsibly oversimplifies the issue of "Christianisation" in Indonesia. It claims from a policy briefing by the International Crisis Group (ICG): "If the growth of Christianity continues at its current rate, by 2035 Indonesia will cease to be a Muslim-majority country." This policy briefing in the video has been dated 24th November 2012 and cannot be found on the ICG website.

However a 2010 policy briefing by the ICG "Christianisation' and Intolerance" sheds light on the situation. It resonates with the concerns outlined in the video such as the use of Arabic calligraphy on the front of Christian conversion booklets applying a false pretense that it maybe Islamic in content. It also speaks of blasphemous incidents and Islamaphobic blogs including one with a photograph of someone standing on the Quran with an obscene hand gesture. A sixteen year old Protestant was held accountable for the photo and spent 1 year in prison. Having such negative views on other religions at such a young age shows the extent of religious intolerance in Indonesia.

What the "Save Maryam" campaign fails to address is the mass mobilisation of terrorism groups who use "Christianisation" as justification for vigilante attacks. The report shows how aggressive evangelical Christian Proselytizing in Muslim strongholds may lead to moderate Muslims and Salafi jihadis 
sharing a platform. The report states that in 2009 some sent to terrorism training in Aceh were encouraged to support attacks on foreign aid workers who were conceived as missionaries trying to convert the Acehnese. It goes on to say terrorism networks have become weaker however systematic exploitation of the fear that Christians are making inroads on Islam might attract new followers. The situation is volatile and it is important to avoid raising tension between religious groupings in both Indonesia and the UK.

The charity behind the campaign, Mercy Mission, has received over 500 donations from the UK alone totaling over

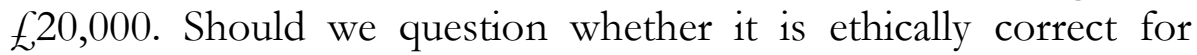
Mercy Mission to have charity status and the ability claim exemption from tax on donations whilst launching irresponsible campaigns?

Thankfully, it seems many of those backing the campaign are focussing on promoting Islam rather than scapegoating the Christian community. The holy month of Ramadan is an important time for Muslims wishing to perform Zakat (charity). Many Muslims may be vulnerable whilst seeking a worthy cause to donate. Some may be susceptible to believing the idea that the Save Maryam campaign is Da'wah - spreading the message of Islam.

However, there is better ways spread the message of Islam primarily through good deeds within the communities we live in. Sharing the knowledge of Islam is worthy, and as the ICG shows, "the right to follow religion is a basic human right" but there is no need to put down competing religions or to indoctrinate people using technology.

In the meantime the charity money could be better spent on a Maryam elsewhere. After all, Maryam could be a child in Palestine in need of healthcare. Or a child in East Africa suffering from insecurity, poverty and disease. She may even be one of the 950 million people in this world who are malnourished. Is money not better spent on food and clean water rather than setting up a TV channel? Essentially, Maryam could be anybody, anywhere, seeking a little help and guidance and there are plenty of pure charities out their willing to take that initiative. 
The contras also called; disappointed and angry are reasonable of humane manner. However, the further they are also invited to take lessons from this issue. One of the lessons that can be taken is to refrain from excessive cursing because tomorrow is not known. They argue that a virtue if it is delivered in the wrong way, it will create new problems. So, be wise; "Save ourselves, just started the people nearby," said the director of the Center for Religious and Cross-Cultural Studies UGM, Mr Zainal Abidin Bagir. According to him, introspecting about the response to this video be something more fundamental, because everyone has their priorities.

They agree that Christianization might exist, but they are invited to respond to this campaign with a more objective, using the compass of religion and science reasoning. They hope, do not let this campaign sparkling luster blind faith and mind. This response can be expected come from academia, visible from the invitation to use logical and objective reasoning. The symptoms seem to be aware of the plurality (reality of plurality) is understood, although not yet going to pluralism.

Save Maryam parties provide testimony related to the originality of this movement, but still needs to be greater clarification given by the video data so striking that it has spread to various people, different countries, different languages, and different religions. Not only clarify that this movement correctly, but also there must be accountability data is bombastic.

As if thousands of Muslim preachers who struggled into the corners of Indonesia has no meaning, as the name of a large organization such as Nahdlatul Ulama and Muhammadiyah also other mass organizations do not pay attention to their own country. This Ramadan, Muslims are getting one of the biggest exams. There are our brothers in Myanmar who are victims of discrimination, thousands died and hundreds of thousands of others in limbo unclear fate. More than 20,000 Muslims are the victims of the massacre in Syria. Still many others in Palestine, Pattani, Iraq, Afghanistan, and others.

Disappointed is a reasonable attitude, angry too humane, but at least than disappointed and angry, we also try to take a lesson on this issue. One is to refrain from excessive cursing, 
because we do not know what will happen tomorrow. The main points we can take from this incident; One favor if presented in the wrong way, it will create new problems.

The pro responses also comes to this campaign with their own arguments and assumptions. They as a Indonesian Muslim feel discomfort because they perceive their weakness has been exceeded. They argue that apostasy maybe real, and the Save Maryam's campaign become reprimand that addressed to Indonesian Muslims to keep fighting aqidah. They concluded that Islam in Indonesia is threatened with extinction because of Christianization. Therefore, again, as a good Muslim, it does not wrong, even got a reward, they are invited and urged to save future lives of Muslims in Indonesia, especially to save young Muslims not to leave Islam by adhering to the ordinance of God. Keep aqiqah, scared because of Christianization, worry that Islam will be extinct: these things are a sign of religious fundamentalism. Obviously, those are an act of intolerance with the reality of religious plurality.

Finally a serious response came through the call and Surat Bersama Warga Indonesia to the Ambassador who was in London, England. Have chose to respond through institutionally; state, government, or the residents of Indonesia Ambassador in London. The appeal says:

1. Require them to pull the video and stop spreading the campaign lies containing. Lies that had been done was the equivalent of criminal cases in terms of falsifying data and disseminate it to the public.

2. Apologize to all the people of Indonesia because it gives the wrong picture.

3. Apologize to all citizens of the world for giving the wrong information.

4. Apologies to those who have given donations for giving misleading information. For, the next, stop raising donations.

To the spreaders video, including the Islamic media, they also look forward to:

1. Promptly clarifications related to programs that do not clear. 
2. If you are not able to make a clarification, simply delete it you post it, because the same thing you are spreading false news in this "holy month".

3. There's also a good idea to apologize, because it helped spread the false news.

4. My expectations of the Government authorities in dealing with this issue:

5. Soon cultivate sensitivity to this issue, so as not to become part of the iceberg that is ready to explode.

6. Give a firm stand to the initiators of the Save Maryam's project.

These responses are more global; think of the effect for the citizens of Indonesia (Indonesian) and citizens of of Islam. These responses are more global; think of the effect for the citizens of Indonesia (Indonesian) and citizens of of Islam.

While the contents of the Surat Bersama Warga Indonesia to the Residents of Indonesia Ambassador in London includes:

Consider that:

1. Save Maryam's campaign threatens harmony among the religious peoples in Indonesia and the integrity of the nation.

2. The case of Save Maryam already become a global issue that defames the image of Muslims in Indonesia and internationally.

3. There are many victims who donated money to the campaign.

4. Maximum efforts; alert to the Mercy Mission World has been done by the citizens of Indonesia both in writing and face to face meetings.

We appeal to Indonesian government as the official representative in the United Kingdom to take decisive action to Mercy Mission World with:

1. Issued an official statement related to the Save Maryam.

2. Reporting Save Maryam's campaign to the Charity Commission and Ofcom.

3. Ask for Mercy Mission to repeal video Save Maryam, freeze the campaign and apologize to all Indonesians.

Amid debate over the pros and contras the various responses that appear address to Save Maryam's video, there are "wise" peoples that want to meet with Mercy Mission World in dialogue. They realized that as the majority of Muslim community 
in Indonesia, they still wanted to khusnuzhon on them, appreciate their attention and keep open the opportunity to discuss with them, if they really had good intentions. However, they gave a note, as a citizen of Indonesia, the act of Mercy Mission World is causing anxiety. Thus, in the context of the state, the competent authority, which is more appropriate to take legal action, is the Government of the Republic of Indonesia. The use of the name "Indonesia", the use of invalid data, and cause unrest is enough to sue them. Of course, while the Indonesian are actively to counter the Save Maryam's campaign. Counter is become a call to re-think critically to share an information. They were invited to ensure the correctness, credibility and usefulness of information.

Moreover, their fear; the video could potentially trigger for inter-religious conflict and radicalization in Indonesia. Again, this response can be expected come from academia, in where they understand and have learned about the reality of the religious conflicts. They are already have the awareness of plurality and pluralism, as well as deep knowledge of religious conflicts; meaning they are in favor of peaceful development.

There are "wise" peoples that want to meet with Mercy Mission World in dialogue. They realized that as the majority of Muslim community in Indonesia, they still wanted to khusnuzhon on them, appreciate their attention and keep open the opportunity to discuss with them, if they really had good intentions. Again, this response can be expected come from academia. They have understood of religious pluralism in Indonesia as a reality. These statements show the importance of the need for inter-religious dialogue in Indonesia.

\section{Conclusion}

The responses toward Save Maryam greatly represent the cultures of toleration in the age of social media. The social medias provide a safe-space to conducting debates toward defining new cultures of toleration in order to show arguments with sometimes defensive, reasonable, and emotional. It also opens opportunities for all kind of people to involve in this culture without hesitation or fear. However, the ethical consideration should be directed in 
conducting this debate in the social media. This is a challenge for future research. []

\section{References}

Dewdney, Andrew and Ride, Peter. the New Media Handbook. London and New York: Routledge, 2006.

Eck, Diana L. "Is Our God Listening? Exclusivism, Inclusivism and Pluralism," in Roger Boase (ed)., Islam and Global Dialogue: Religious Pluralism and the Pursuit of Peace. Burlington: Ashgate, 2005.

Hoover, Stewart M. Religion in the Media Age. London and New York: Routledge, 2006.

Husein, Fatimah. Muslim-Christian Relations in the New Order Indonesia: the Exclusivist and Inclusivist Muslims' Perspectives. Bandung: Mizan, 2005.

Iwuchukwu, Marinus. "Engaging the Media as Effective Tools for Interreligous Dialogue in Multi-religious Societies: a Catholic Evaluation," Journal of Inter-Religious Dialogue, March 2010.

Kuntowijoyo, Muslim Tanpa Masjid: Esai-esai Agama, Budaya dan Politik dalam Bingkai Strukturalisme Transendental. Bandung: Mizan, 2001.

The Doyle Building Tolerance Initiative, "Bridging Babel: New Social Media and Interreligious and Intercultural Understanding," 2010 Undergraduate Fellows Report, Berkeley Center for Religion, Peace and World Affairs, April 2010.

\section{Jurnal:}

Mandaville, Peter. "Globalization and the Politics of Religious Knowledge: Pluralizing Authority in the Muslim World," Theory, Culture and Society Vol. 24 (2), 2004, pp. 101-115.

Swidler, Leonard. "The Dialogue Decalogue," Journal of Ecumenical Studies, 2003.

Turner, Bryan S. "Religious Authority and the New Media," Theory, Culture and Society Vol. 24 (2), 2007, pp. 117-134. 
Van Dijck, Jose. "You Have One Identity: Performing the Self on Facebook and Linkedln," Media, Culture and Society 35 (2), 2013, pp. $199-215$.

\section{Internet:}

savemaryam.com

saveudin.com

Van Klinken, Gerry. "What Caused the Ambon Violence?" Inside Indonesia, no. 60 (Oct-Dec 1999) available at http://www.insideindonesia.org/weekly-articles/whatcaused-the-ambon-violence, retrieved on March 12, 2013. 